ukrainskoi shkoly [Pedagogy of partnership as a factor in the formation of effective interaction of participants in the educational process in the New Ukrainian school]. Hirska shkola Ukrainskykh Karpat. № 21. S. 50-54. [in Ukrainian].

Nikolenko, L. (2018). Pedahohika partnerstva yak umova realizatsii zavdan rozvytku osobystosti dytyny u konteksti Novoi ukrainskoi shkoly [Pedagogy of partnership as a condition for the implementation of tasks of child personality development in the context of the New Ukrainian school]. Metodyst. № 6. URL: https://core. ac.uk/download/pdf/158553923.pdf (data zvernennia: 16.10.2020). [in Ukrainian].

Pometun, O. (2014). Entsyklopediia interaktyvnoho navchannia. [Encyclopedia of interactive learning]. Istoriia i suspilstvoznavstvo v shkolakh Ukrainy: teoriia ta metodyka navchannia. № 5/6 (8). S. 95. [in Ukrainian].
Nova ukrainska shkola. Kontseptualni zasady reformuvannia serednoi shkoly [New Ukrainian school. Conceptual principles of secondary school reform]. URL: https:// mon.gov.ua/storage/app/media/zagalna\%20serednya/nova-ukrainska-shkola-compressed.pdf (data zvernennia: 10.11.2020). [in Ukrainian].

Pro osvitu: Zakon Ukrainy vid 05.09.2017 r. № 2145-VIII [Law of Ukraine «On Education»]. URL: http://search. ligazakon.ua/1_doc2.nsf/link1/T172145.html (data zvernennia: $12.10 .20 \overline{20})$. [in Ukrainian].

Skyba, M. (2019). Krashche razom. Shcho take pedahohika partnertsva i navishcho vona v NUSh [What is the pedagogy of partnership and why is it in NUS]. URL: https://nus.org.ua/articles/pedagogika-partnerstva-shho-tse-take-ta-yak-zrozumity-chy-vona-ye-u-shkoli/ (data zvernennia: 02.11.2020). [in Ukrainian].

Дата надходження до редакиії: 21.01.2021 p.

УДК 378.147

DOI: 10.37026/2520-6427-2021-105-1-75-79
Едуард САЛЕЙЧУК,

аспірант кафедри початкової та дошкільної освіти ПВНЗ «Міжнародний економіко-гуманітарний університет імені академіка С. Дем'янчука», м. Рівне, Украӥна

ORCID: 0000-0002-7513-4367

e-mail:edik_saleichuk@ukr.net

\title{
ТЕОРЕТИКО-ПРИКЛАДНИЙ КОНТЕКСТ ПОНЯТТЯ «ТВОРЧИЙ ПОТЕНЦАЛ» У ПСИХОЛОГО-ПЕДАГОГІЧНІЙ ЛІТЕРАТУРІ
}

\begin{abstract}
Анотація. У статті досліджено поняття «творчий потенціал» у психолого-педагогічній літературі. Проаналізовано праці науковців з означеної проблеми. Доведено, щуо теоретичні та практичні дослідження щодо визначення сутності, ознак та структури творчого потениіалу не дають єдиного трактування иъього феномену. Обтрунтовано, щзо творчий потенціал широко вивчається у різних аспектах, зокрема філософському, педагогічному і психологічному. Схарактеризовано представлене поняття у психологічному дискурсі як сукупність умінь, навичок, можливостей особистості, що визначають ії здатність до здійснення творчої діяльності. Доведено, щуо творчий по-
\end{abstract}

тенціал має неактуалізовану форму, основними його ознаками є комплексність, динамічність, прихованість від зовнішніх спостережень. В означеному контексті аналізоване поняття розглядається як сукупність здібностей і можливостей, якість або здібність особистості, атрибутивна чи інтегративна властивість. Визначено, шо у педагогічній науці основними характеристиками творчого потенціалу є здатність до перетворювальної діяльності та саморозвитку, котра виявляється у продукті творчої діяльності та є виявом сутності особистості.

Ключові слова: потенціал, творчий потенціал, професійна освіта, майбутні вчителі.

\author{
Eduard SALEYCHUK, \\ postgraduate student in the Department of \\ Primary and Preschool Educatio, \\ Academician Stepan Demianchuk International \\ University of Economics and Humanities, \\ Rivne, Ukraine \\ ORCID: 0000-0002-7513-4367 \\ e-mail:edik_saleichuk@ukr.net
}

\section{THE CONCEPT OF «CREATIVE POTENTIAL» IN PSYCHOLOGICAL AND PEDAGOGICAL LITERATURE}

\author{
Abstract. The article explores the concept of "creative \\ potential" in the psychological and pedagogical literature.
}

The works of scientists on the researched problem are analyzed. It is determined that theoretical and practical research 
on the problem of determining the essence, features and structure of creative potential do not give a single interpretation of this phenomenon. It is defined that in general, potential should be understood as opportunities or resources that can be used or that can be activated under the influence of favorable conditions. It is substantiated that the creative potential is widely explored in various aspects, including philosophical, pedagogical and psychological. It is determined that creative potential is one of the main internal potentials of the individual, it is possessed by every person, but it is not always actualized and revealed. It is characterized that in psychological discourse creative potential is considered mainly as a set of skills, abilities, capabilities of the individual that determine his ability to perform creative activities, and the main features of creative potential are complexity, dynamism, secrecy from external observations, creative potential has outdated form. It is determined that from the point of view of pedagogical science the creative potential is usually considered either as the creative potential of the one who is taught (pupil, student) and the one who teaches and is based on psychological research. It is investigated that from the pedagogical aspect the creative potential can be considered as: set of abilities and possibilities, quality or ability of the person, attributive or integrative property. It is determined that in pedagogical thought the main characteristics of creative potential are the ability to transform, self-development, and creative potential is manifested in the product of creative activity, which is a manifestation of the essence of personality.

Key words: potential, creative potential, professional education, future teachers.

Постановка проблеми. Сучасна система вищої освіти та професійна освіта зокрема перебувають у процесі модернізації. Цьому спряють науково-технічний прогрес, поширення інформаційної свободи, вплив європейського освітнього простору в умовах інтеграції, зміна психолого-суспільних якостей молодого покоління та вимог роботодавців щодо фахової компетентності майбутнього спеціаліста. Основною характеристикою особистості, завдяки якій здійснюється перетворювальна діяльність, є творчий потенціал, що сприяє прогресу та удосконаленню. У зв'язку з цим важливим аспектом професійної підготовки майбутнього фахівця є розвиток творчого потенціалу.

Аналіз наукових досліджень і публікацій. Дослідженню творчого потенціалу присвячена значна кількість наукових праць, зокрема напрацювання Б. Ананьєва, В. Андрєєва, Д. Богоявленської, Л. Виготського, Н. Вишнякової, В. Давидова, Д. Ельконіна, Н. Кузьминої, О. Матюшкіна, В. Моляко, О. Музики, Я. Пономарьова, С. Рубінштейна, М. Холодної, I. Якиманської, Дж. Гілфорда, А. Маслоу, Дж. Рензуллі, Е. Торренса та ін. Означені напрацювання $є$ підгрунтям для подальшого вивчення цього феномену, адже на сьогодні не існує єдиного погляду на сутність, структуру та ознаки творчого потенціалу особистості.

Мета статті - здійснити аналіз поняття «творчий потенціал» у психолого-педагогічній літературі.

Виклад основного матеріалу дослідження. Щодо визначення поняття «потенціал», то відмінності потенційного та актуального, можливості й дійсності мають давню традицію дослідження у світовій культурі та філософії.

У словниках української мови потенціал тлумачиться як: ресурс, заряд, запас, резерви (внутрішні, жит- тєві), можливості (Словник української мови, 2010); сукупність усіх наявних засобів, можливостей, продуктивних сил тощо, що можуть бути використані в певній галузі, діяльності, сфері; запас чого-небудь, приховані здатності, сили для відповідної діяльності, що можуть виявитися за певних умов (Великий тлумачний словник сучасної української мови, 2002, с. 902). Таким чином, загалом під потенціалом слід розуміти можливості чи ресурси, що можуть бути використані, або які можуть бути активізовані під впливом сприятливих умов.

Творчий потенціал є одним із основних внутрішніх потенціалів особистості, ним володіє кожна людина, однак він не завжди є актуалізованим та виявленим. Американські та французькі дослідники Б. Барбот, М. Безансон та Т. Люббарт (2015, с. 371-381) дійшли висновку, що за півстоліття наукових досліджень творчого потенціалу особистості вчені так і не прийшли до консенсусу щодо творчого потенціалу людини та його структури. Означена проблема на сучасному етапі досить ускладнює розвиток творчого потенціалу дітей у системі освіти, а тому залишається досить актуальною у педагогічній теорії та практиці. Оскільки поняття «творчий потенціал» $є$ міждисциплінарним феноменом і може розглядатися у різних аспектах, ми схарактеризуємо сутність цієї дефініції у педагогічному та психологічному аспектах.

У психологічному дискурсі творчий потенціал трактується переважно як сукупність умінь, навичок, можливостей особистості, що визначають ії здатність до здійснення творчої діяльності. Французький учений Ф. Полан (1980) трактував творчий потенціал особистості як прояв комплексу якостей людської волі, вважаючи, що чим організованіша й розвиненіша воля, тим більше сформований творчий потенціал. На думку I. Кона (1989), означена дефініція включає в себе всі властивості особистості - мислення, волю, пам'ять, знання, переконання.

Творчий потенціал особистості І. П. Маноха (2002, c. 285) пропонує розглядати як «складно організовану багатокомпонентну структуру, що охоплює основні види творчої активності особистості (візуальну, вербальну, реконструктивну, текстову, образно-евристичну, інтелектуально-мислительну та синтетичну творчість) за ознакою створюваного (у процесі творення) продукту (візуального, вербального, текстового та інших образів). Як динамічна структура особистості творчий потенціал передбачає комплекс творчих задатків, які виявляються і розвиваються безпосередньо у творчій діяльності, а також комплекс психічних новоутворень особистості впродовж iї вікового дозрівання. Він базується на уявленні та фантазії, асоціативних зв'язках, багатстві інтуїтивних процесів, емоційній різноманітності й емпатійних почуттях, що здійснюються у процесі творчої діяльності».

Характеристиками творчого потенціалу є такі його складові:

- творча спрямованість інтересів, зокрема професійних;

- потреба у новаторській діяльності;

- схильність до інновацій;

- високий рівень загального і деяких спеціальних видів інтелекту;

- схильність до формування асоціативних зв'язків; - розвинута уява; 
- сформована вольова регуляція поведінки і діяльності;

- самостійність;

- саморегуляція (Деркач, Зазикін, 2003, с. 172).

Н. В. Кузьміна (1995, с. 46) виокремила низку елементів творчого потенціалу спеціаліста, зокрема:

1) індивідуальні якості (стать, вік, структура сім'ї, координати народження, стан здоров'я);

2) рівень продуктивності діяльності в розв'язанні творчих завдань (найвищий, високий, середній та ін.);

3) інтегративні схеми інформаційного самозабезпечення, рольової взаємодії, аналізу зворотного зв'язку у ході розв'язання творчих задач;

4) психологічні передумови продуктивного розв'язання творчих задач (система ставлень), установки, цінності, спрямованість, мотивація;

5) здібності, структура компетентності;

6) когнітивні, емоційні та вольові якості суб'єкта у процесі розв'язання творчих задач;

7) структура вмінь (гностична, проєктувальна, конструктивна, комунікативна, організаційна);

8) вплив контексту (професійного, непрофесійного, сімейного оточення);

9) соціальний вплив (оцінка, заохочення, підтримка, соціальна роль);

10) психологічна готовність до перебудови (реконструювання) діяльності у пошуках нових способів розв'язання творчих задач (самооцінка, інтернальність, екстернальність, догматизм, інтуїція);

11) способи врахування системи обмежень та вимог до розв'язання творчих задач, обумовлених професією та виробництвом;

12) способи врахування системи вимог та обмежень до розв'язання задач, обумовлених моральними принципами.

На думку В. О. Моляко (2006, с. 17), у представленій структурі творчого потенціалу репрезентований великий перелік основних елементів, що зумовлює, 3 одного боку, труднощі суто психологічного дослідження означеного феномену, а з іншого - необхідність системності, комплексності, міждисциплінарності в загальному масиві досліджень. Звідси вчений виокремлює (Моляко, 2006, с. 15-16) такі основні складові творчого потенціалу особистості:

1) задатки, нахили, що виявляються в підвищеній чутливості, певній вибірковості, наданні переваг чомусь перед чимось, загальній динамічності психічних процесів;

2) інтереси, їх спрямованість, частота й систематичність проявів, домінування пізнавальних інтересів;

3) допитливість, потяг до створення нового, до пошуку й розв'язання проблем;

4) швидкість у засвоєнні нової інформації, створення асоціативних масивів;

5) нахили до постійних порівнянь, зіставлень, вироблення еталонів для наступних порівнянь та відбору;

6) прояви загального інтелекту - розуміння, швидкість оцінювань та вибору шляхів розв'язку, адекватність дій ;

7) емоційне забарвлення окремих процесів, емоційне ставлення, вплив почуттів на суб'єктивне оцінювання, вибір, надання переваг;

8) наполегливість, систематичність у роботі, цілеспрямованість, рішучість, працелюбність, сміливе прийняття рішень;

9) творча спрямованість на пошуки аналогій, комбінування, реконструювання, зміни варіантів, економність у рішеннях, використанні часу, засобів тощо;

10) інтуїтивізм - здатність до прояву неусвідомлюваних швидких (іноді миттєвих) оцінок, прогнозів, рішень;

11) порівняно швидке та якісне оволодіння вміннями, навичками, прийомами, технікою праці, майстерністю виконання відповідних дій;

12) здібності до вироблення власних стратегій та тактик у ході розв'язання різних проблем, завдань, пошуків виходу зі складних, нестандартних, екстремальних ситуацій.

Із позиції педагогічної науки, творчий потенціал зазвичай розглядається як творчий потенціал того, кого навчають (учень, студент) і того, хто навчає і зважає на психологічні дослідження (викладач, учитель). Здійснивши аналіз наукових праць, ми з'ясували, що у педагогічному дискурсі не має одностайної думки щодо дефініції творчого потенціалу. Так, було представлено декілька провідних поглядів щодо визначення сутності цього феномену.

Сукупність здібностей і можливостей. А. В. Лукановська $(2010$, с. 634$)$ зазначає, що творчий потенціал можна представити у вигляді сукупності перетворювально предметних (навички, вміння, здібності), пізнавальних (інтелектуальні здібності), аксіологічних (ціннісні орієнтаціі), комунікативних (морально психологічні якості), художніх (естетичні здібності) можливостей.

В. Д. Лихвар (2003, с. 17) конкретизує поняття i визначає творчий потенціал як сукупність творчих здібностей, необхідних для творчої діяльності, та зазначає, що рушійною силою і ядром реалізації творчого потенціалу $є$ внутрішні фактори особистості, котрі $\epsilon$ важливими чинниками саморозвитку людини, самореалізації, самодіяльності, вільних дій і вчинків. Творчий потенціал особистості включає як здатності, які нереалізовані, так і здатності, що вже проявилися в діяльності. Творчий потенціал особистості $є$ ширшим від будь-якої конкретної діяльності, це не просто констатація того, що є в дійсності, а й того, що існує лише як можливість (Байгільдіна, 2009, с. 695-696). На думку П. Ф. Кравчука (1984, с. 24), творчий потенціал виявляється насамперед у здатності особистості підходити до конкретної справи нестандартно, шукати і знаходити найбільш оптимальні шляхи, ефективні методи вирішення проблем, що виникли.

Якість або здібність особистості. Б. Ф. Кекух $(1993$, c. 6) характеризує творчий потенціал як творчу здібність - результат тривалого процесу формування особистості, суспільства на шляху свого розвитку. Щодо конкретної людини він виявляється під час навчання, оволодіння кваліфікацією, формування навичок творчого мислення, використання певних стимулів. За О. І. Клепіковим та I. Т. Кучерявим (1996, с. 34), творчий потенціал - це якість людини, за допомогою якої реалізується наявна і можлива діяльність у формі праці, пізнання і спілкування; iï зміст і характер відзначаються новизною. Як вияв сутності особистості творчий потенціал має фізіологічну, психологічну та соціальну сторони.

Атрибутивна якість особистості. Як зазначає Т. О. Саламатова (2003, с.56) творчий потенціал 
відображає здатність людини до саморозвитку через подолання внутрішніх суперечностей.

Інтегративна якість особистості. О. Б. Шульц (2005) розглядає творчий потенціал особистості як інтегративну властивість, що відображає міру можливостей реалізації іï творчих сил, як «сукупність проявів особистісних функцій, що спрямовані на вирішення зовнішніх та внутрішніх проблем особистості з метою перетворення оточуючого світу та себе».

Найбільш повним вважаємо визначення М. Д. Дяченко (2014, с. 160): «творчий потенціал - складна інтегральна особистісно-діяльнісна характеристика людини, що включає в себе інтелектуальний, мотиваційний і саморозвивальний компоненти, які відображають сукупність особистісних якостей і здібностей особистості, iї психологічний стан, знання, вміння та навички, необхідні для здійснення розвитку й саморозвитку особистості шляхом актуалізації власних творчих сил і можливостей».

Висновки. Отже, теоретичні та практичні дослідження щодо проблеми визначення сутності, ознак та структури творчого потенціалу не дають єдиного трактування цього феномену. Творчий потенціал широко досліджують у різних аспектах, зокрема філософському, педагогічному та психологічному. У психологічному дискурсі означене поняття розглядають переважно як сукупність умінь, навичок, можливостей особистості, що визначають їі здатність до здійснення творчої діяльності. Основними ознаками творчого потенціалу є комплексність, динамічність, прихованість від зовнішніх спостережень.

У педагогічній думці творчий потенціал може розглядатись як: сукупність здібностей і можливостей; якість або здібність особистості; атрибутивна чи інтегративна властивість. Основними характеристиками творчого потенціалу є здатність до перетворювальної діяльності, саморозвитку. Він виявляється у продукті творчої діяльності, що є виявом сутності особистості.

Перспективи подальших досліджень вбачаємо в розкритті сутності професійної підготовки майбутніх учителів географії до творчої педагогічної діяльності.

\section{СПИСОК ВИКОРИСТАНОЇ ЛІТЕРАТУРИ}

Словник української мови: у 20 т. Т. 8: П-Р. (2010). Київ: Наукова думка. 911 с.

Великий тлумачний словник сучасної української мови. (2002) / уклад. і гол. ред. В. Т. Бусел. Київ; Ірпінь: Перун. 1428 с.

Barbet, B., Besançon, M., Lubart, T. (2015). Creative potential in educational settings: its nature, measure and nurture. Education. 3-13. 43(4). Pp. 371-381.

Проблемы научного творчества: сборник аналитических обзоров. (1980). Москва: Академия наук СССР; Институт научной информации по общественным наукам. 228 с.

Кон, И. С. (1989). Психология ранней юности. Москва: Просвещение. 255 с.

Маноха, І. П. (2002). Психологія потенціалу індивідуального буття людини: онтологічно орієнтований підхід: дис. д-ра психол. наук / Київ. нац. ун-т ім. Тараса Шевченка. 462 с.

Деркач, А., Зазыкин, В. (2003). Акмеология: учебное пособие. Санкт-Петербург: Питер. 256 с.
Кузьмина, Н. В. (1995). Творческий потенциал специалиста. Акмеологические проблемы развития. Гуманизация образования: психолого-педагогический международный журнал. № 1. С. 41-53.

Моляко, В. О. (2006). Творчий потенціал людини як психологічна проблема. Здібності, творчість, обдарованість: теорія, методика, результати досліджень. Житомир: Вид-во ПП «Рута». С. 13-31.

Лукановська, А. В. (2010). Творчий потенціал особистості: структурні компоненти. Проблеми сучасної психологї: збірник наукових праць КПНУ імені Івана Огіснка, Інституту психології ім. Г. С. Костюка АПН України. Вип. 8. С. 630-644.

Лихвар, В. Д. (2003). Розвиток художньо-творчого потенціалу молодших школярів у процесі образотворчої діяльності: автореф. дис. ... канд. пед. наук / Херсон: Херсонський держ. ун-т. 24 с.

Байгильдина, 3. Ф. (2008). Творческий потенциал личности. Вестник Башкирского университета. Т. 13. №3. С. 693-696.

Кравчук, П. Ф. (1984). Формирование развитой творческой личности студента (философско-социологический и методический анализ). Киев: Высшая школа. 154 с.

Кекух, Б. Ф. (1993). Творчество: краткий словарь. Луцк. $121 \mathrm{c}$.

Клепіков, О. І., Кучерявий, І. Т. (1996). Основи творчості особи: навчальний посібник для студ. вищ. навч. закладів. Київ: Вища школа. 295 с.

Саламатова, Т. А. (2003). Актуализация творческого потенциала личности в процессе изучения педагогических дисциплин: дис. канд. пед. наук. Москва. 231 с.

Шульц, О. Б. (2005). Развитие творческого потенциала учащихся в личностно-ориентированном образовании: дис. канд. пед. наук: 13.00.01. Ростов-на-Дону. 183 с.

Дяченко, М. Д. (2014). Творчий потенціал як системоутворювальна ознака креативної особистості: теоретичний аспект. Педагогіка формування творчої особистості у вищій $і$ загальноосвітній школах. Вип. 35 (88). С. 149-163.

\section{REFERENCES}

Slovnyk ukrainskoi movy [Dictionary of the Ukrainian language]: u 20 t. T.8: P-R. (2010). Kyiv: Naukova dumka. 911 s. [In Ukrainian].

Busel, V. T. (2002). Velykyi tlumachnyi slovnyk suchasnoi ukrainskoi movy [Large explanatory dictionary of the modern Ukrainian language]. Kyiv; Irpin: Perun. 1428 s. [In Ukrainian].

Barbet, B., Besançon, M., Lubart, T. (2015). Creative potential in educational settings: its nature, measure, and nurture. Education 3-13. 43(4). Pp. 371-381. [in English].

Problemy nauchnogo tvorchestva: sbornik analiticheskih obzorov [Problems of scientific creativity: a collection of analytical reviews]. (1980). Moskva: Akademyia nauk SSSR; Ynstytut nauchnoi ynformatsyy po obshchestvennыm naukam. 228 s. [In Russian].

Kon, I. S. (1989). Psihologija rannej junosti [Psychology of early adolescence]. Moskva: Prosveshchenye. 255 s. [In Russian].

Manoha, I. P. (2002). Psykholohiia potentsialu indyvidualnoho buttia liudyny: ontolohichno oriientovanyi pidkhid [Psychology of the potential of individual human existence: an ontologically oriented approach]: dys. d-ra 
psykhol. nauk / Kyiv. nats. un-t im. Tarasa Shevchenka. 462 s. [In Ukrainian].

Derkach, A., Zazykin, V. (2003). Akmeologija [Acmeology]: uchebnoe posobie. Sankt-Peterburh: Pyter. $256 \mathrm{~s}$. [In Russian].

Kuzmina, N. V. (1995). Tvorcheskyi potentsyal spetsyalysta. Akmeolohycheskye problemы razvytyia [The creative potential of a specialist. Acmeological problems of development]. Humanyzatsyia obrazovanyia: psykholoho-pedahohycheskyi mezhdunarodnыi zhurnal. № 1. S. 41-53. [In Russian].

Molyako, V. O. (2006). Tvorchyi potentsial liudyny yak psykholohichna problema [The creative potential of man as a psychological problem]. Zdibnosti, tvorchist, obdarovanist: teoriia, metodyka, rezultaty doslidzhen. Zhytomyr: Vid-vo PP «Ruta». S. 13-31. [In Ukrainian].

Lukanovska, A. V. (2010). Tvorchyi potentsial osobystosti: strukturni komponenty [Creative potential of personality: structural components]. Problemy suchasnoi psykholohii: zbirnyk naukovykh prats KPNU imeni Ivana Ohiienka, Instytutu psykholohii im. H. S. Kostiuka APN Ukrainy. Vyp. 8. S. 630-644. [In Ukrainian].

Likhvar, V. D. (2003). Rozvytok khudozhno-tvorchoho potentsialu molodshykh shkoliariv u protsesi obrazotvorchoi diialnosti [Development of artistic and creative potential of junior schoolchildren in the process of art activity]: avtoref. dys. ... kand. ped. nauk / Kherson. derzh. un-t. Kherson. 24 s. [In Ukrainian].

Bajgil'dina, Z. F. (2008). Tvorcheskij potencial lichnosti [The creative potential of the individual].
Vestnyk Bashkyrskoho unyversyteta. T. 13. №3. S. 693696. [In Russian].

Kravchuk, P. F. (1984). Formirovanie razvitoj tvorcheskoj lichnosti studenta (filosofsko-sociologicheskij i metodicheskij analiz) [Formation of a developed creative personality of a student (philosophical, sociological and methodical analysis)]. Kyev: Vыsshaia shkola. 154 s. [In Russian].

Kekuh, B. F. (1993). Tvorchestvo [Creativity]: kratkij slovar'. Luck. 121 s. [In Russian].

Klepikov, O. I., Kucheriavyi, I. T. (1996). Osnovy tvorchosti osoby [Fundamentals of personal creativity]: navchalnyi posibnyk dlia stud. vyshch. navch. zakladiv. Kyiv: Vyshcha shkola. 295 s. [In Ukrainian].

Salamatova, T. A. (2003). Aktualyzatsyia tvorcheskoho potentsyala lychnosty $\mathrm{v}$ protsesse yzuchenyia pedahohycheskykh dystsyplyn [Actualization of the creative potential of the individual in the process of studying pedagogical disciplines]: dys. kand. ped. nauk. Moskva. 231 s. [In Russian].

Shul'c, O. B. (2005). Razvytye tvorcheskoho potentsyala uchashchykhsia $v$ lychnostno-oryentyrovannom obrazovanyy [Development of the creative potential of students in student-centered education]: dys. kand. ped. nauk: 13.00.01. Rostov-na-Donu. 183 s. [In Russian].

Dyachenko, M. D. (2014). Tvorchyi potentsial yak systemoutvoriuvalna oznaka kreatyvnoi osobystosti: teoretychnyi aspect [Creative potential as a system-forming feature of creative personality: theoretical aspect]. Pedahohika formuvannia tvorchoi osobystosti $u$ vyshchii $i$ zahalnoosvitnii shkolakh. Vyp. 35 (88). S. 149-163. [In Ukrainian].

Дата надходження до редакиії: 21.01.2021 p. 